\title{
THE IMPACT OF INCUBATORS ON ENTREPRENEURIAL PROCESS IN TURKEY: A GUIDE FOR STARTUPS
}

\author{
DOI: 10.17261/Pressacademia.2020.1219 \\ JBEF- V.9-ISS.2-2020(6)-p.132-142
}

\section{Muge Birden ${ }^{1}$, Murat Bastug ${ }^{2}$, Selim Yazici ${ }^{3}$}

${ }^{1}$ Istanbul University, Department of Business Administration, Management and Strategy PhD. Candidate, Istanbul, Turkey. muge.birden@ogr.iu.edu.tr, ORCID: 0000-0002-1042-3635

${ }^{2}$ Nisantasi University, Vocational School, Department of Business Management, Istanbul, Turkey. murat.bastug@nisantasi.edu.tr , ORCID: 0000-0002-6406-2468

${ }^{3}$ Istanbul University, Faculty of Political Sciences, Department of Business Administration, Istanbul, Turkey. selim@istanbul.edu.tr , ORCID: 0000-0001-7953-2496

Date Received: April 16, 2020

Date Accepted: June 12, 2020

To cite this document

Birden,M., Bastug, M., Yazici, S. (2020). The impact of incubators on entrepreneurial process in Turkey: a guide for startups. Journal of Business, Economics and Finance (JBEF), V.9(2), p.132-142.

Permanent link to this document: http://doi.org/10.17261/Pressacademia.2020.1219

Copyright: Published by PressAcademia and limited licensed re-use rights only.

\section{ABSTRACT}

Purpose The purpose of this study is to analyze the impact of the incubators on entrepreneurial processes in Turkey.

Methodology- We divided incubators in the sample universe into four different categories that are business based, university-private based, university-based and municipality incubators. We deciphered semi-structured and the face-to-face interviews, which were conducted in the incubation determined by the expert opinion, and interpreted the findings in the light of the purpose of the study.

Findings- We can conclude that there is a significant increase in the number of incubation centers and startups in Turkey where incubators help develop startups by providing advisory and administrative support services.

Conclusion- In general, the financial reasons and the need for convenient access make this criterion a vital one. However, it is also significant in terms of its proximity to the business center and the transportation network of the city, and its high accessibility for mentors.

Keywords: Incubator, incubator models, entrepreneurship, entrepreneurship process, Turkey.

JEL Codes: L26, M13

\section{INTRODUCTION}

Incubator means a container in which a weak or a premature baby can be kept alive through the controlled air and temperature conditions (Cambridge Dictionary, 2019). On the other hand, in business English, an incubator means an organization that helps people to start new companies, especially the ones involved with advanced technology (Cambridge Dictionary, 2019).

The business incubator is a new concept in enterprise and economic development, which benefits from extensive, mostly old, structures to house new small businesses (Fry, 1987). Defining and explaining the concept of "incubator" became a challenging task during the adaptation period of the original idea to meet the needs of the economy-related areas (Kuratko and LaFollette, 1987). Allen and Nyrop (1985) point out that it is common to hear the term used to encompass enterprises ranging from low-rent buildings providing space for more than one tenant to generic business assistance programs that operate throughout a community, the so-called "incubators without walls." However, if incubators are everything to everyone, they assume no place as a unique enterprise development tool.

One of the key aspects of this relatively recent phenomenon is the concentration of firms and resources in a single area (Lumpkin and Ireland, 1988). Within this context, the main aim is to organize a business incubator accordingly to provide cost-sparing, timesaving, and skill-developing services in a centralized and controlled platform (Allen and Rahman, 1985). As Galante (1987) states, incubators are ". . . large buildings operated to nurture young companies by giving low-lease space, shared office services and administration advice." 
According to Kuratko and LAFollette (1987), research studies (Humprey Institute, 1984; Allen and Nyrop, 1985; Allen and Rahman, $1985)$ have identified four main types of incubators:

Publicly-sponsored: These type of incubators are organized and managed through city economic development departments, urban renewal authorities, or regional planning and development commissions. Job creation is the main object of publiclysponsored incubators.

Nonprofit-sponsored: These are organized and managed through industrial development associations of private industry, chambers of commerce, or community-based organizations with broad community support and a favorable record in real estate development. Urban development is the objective of nonprofit-sponsored incubators.

University-related: Many of these university-organized and managed facilities are spinoffs of academic research projects. Most of these are considered science and technology incubators. The goal of university-related incubators is to transfer the findings of basic research and development into new products or technologies, thus creating economic growth.

Privately-sponsored: These are organized and managed by private corporations. Their goal is, of course, to make a profit and, in some cases, to make a contribution to the community or the company by finding the right business partner from the first hand. Most often, though, it is a business, and thus, the goal is to make a profit.

Some researchers have attempted to conceptualize incubator formation and, to a limited extent, the process of incubation (Hackett and Dilts, 2004). Building on the survey data collected by Temali and Campbell (1984), and Campbell et al. (1985) develop a framework offering the first apparent linkage of the incubator-incubation concept to the business development process of incubatees, which mean companies registered under an incubator and in service for a period of time. This framework proposes four areas where incubators and incubation processes create value: the diagnosis of business needs, the selection and monitored application of business services, the provision of financing, and the provision of access to the incubator network. Apparently, with this framework, Campbell et al. have normatively defined the incubation process. This definition is practical since, for the first time, it thoroughly elaborates on how different components of, and activities within, the incubators are applied to help transform an idea into a feasible business. However, the framework fails to explain unsuccessful ventures (it assumes that all incubator tenants succeed), and to embrace all incubators but not limited to private ones (Hackett and Dilts, 2004).

\section{THEORETICAL FRAMEWORK}

The incubator development addresses the question of "what is an incubator?" and is engaged in descriptive and normative theorizing about the incubator-incubation concept. The primary formal hypothesis put forward to explain incubators is as follows: After controlling or eliminating extraneous factors that lead to early-stage failure in small businesses (poor management, inability to find early-stage financing, high overhead, etc.), the projected increased survival rate of new ventures should lead to increased employment and an expanded tax base (Brooks, 1986). This theory was utilized to address the gap between conceiving the new business concept and instantiating the firm. Brooks (1986) argues that the concepts of the incubator and incubation processes were necessary to narrow this gap. Transaction Cost Economics (TCE) can also be considered as another viewpoint to bridge the gap. Within the TCE view, a firm gains a competitive advantage by relentlessly lowering the costs of doing business (Williamson, 1975). From this point of view, the essential function of an incubator is to bridge the gap by reducing the startup and other operating expenditures of incubatees by providing shared office space and other services at a low cost. This situation frees the incubatee administration team to focus on forming the business and the market. A related hypothesis suggests that incubators aim at assisting entrepreneurs in developing their business enterprises in a supportive business environment. Without an incubator, most entrepreneurs would either not be in business or struggle to remain in business (Plosila and Allen, 1985).

This hypothesis is a "market failure argument" and is complemented by research that regards incubators as mechanisms for empowering a firm "to master the competitive factors linked with effectiveness within particular industry settings" (Lumpkin and Ireland, 1988). Whereas such presumptions are both intuitively compelling and hard to disprove, many incubatees report that they would have established their firms even if the incubators had not existed (Culp, 1996). These reports should not be necessarily taken as a proof against the incubator-incubation concept; however, as the courage and motivation required to launch a new enterprise may also be associated with unreasonable levels of confidence concerning personal capabilities and success (Nye, 1991).

Even though the incubator configuration studies were theoretical, inductive compilations of variables of the incubator-incubation phenomenon, this approach implicitly rests on Structural Contingency Theory (Hackett and Dilts, 2004). The primary assumption of structural contingency theory is that the configuration of an organization and the external environment must achieve "fit" to 
obtain "success" (Ketchen et al., 1993). Even though most configuration studies do not test for success, structural contingency theory provides a theoretical underpinning for the mostly asserted need for the incubator to be tailored to meet local needs and standards. (Hackett and Dilts, 2004).

Rice (2002) explicitly grounds the collaborative incubator manager-incubatee relationship in the interdependent co-production condition. These condition models the co-creation aspects of the value-adding incubation process. It suggests that incubator managers must carry out business assistance intervention sessions for incubatees at strategically allocated time intervals and need to prepare an appropriate environment to make them to take advantage of advice and insights resulting from the intervention (Rice, 2002). This viewpoint is significant as it diverts our attention away from the incubator facility and makes us focus on the incubation process itself. It also reminds us of the significance of evaluating the core competencies of an incubator before entering and deciding if an incubator and an incubatee are a good fit. If there is no fit, the interdependent co-production may result in inappropriate, value subtracting incubation processes (Hackett and Dilts, 2004).

Commercialization usually happens within an innovation community rather than a single organization (Lynn et al., 1996). Hansen et al. (2000) employ Network Theory (Nohria and Eccles, 1992) to contend that primary value-added feature of networked incubators is the set of systemic forms carefully structuring and transferring knowledge throughout the incubator network to create conditions that facilitate the development of incubatees and the commercialization of their innovations. They find that degree of entrepreneurial intensity, economies of scale and scope, and network plan are significant factors for successful incubation processes. The research indicating that network relationship-building is the most significant value-added component of the incubation process underlines the importance of the network plan factor (Lichtenstein, 1992).

Network theory is also practical since it helpfully addresses the argument concerning the location of the incubation process: Rather than locating the process either inside an incubator or in a local community, network theory states that the incubation process includes and transcends the incubator (Hackett and Dilts, 2004).

\section{EVOLUTION OF INCUBATORS}

The concept of entrepreneurial development centers appears mixed in the description of form, function, purpose, and outcomes. The oldest and most common one is incubators.

\subsection{The First Era between 1959 and 1970}

The Batavia Industrial Center, which is the first known incubator, was established in 1959 by Joseph L. Mancuso in Batavia, New York. It mainly aimed to create jobs in the region when its local economy was stagnant. It adopted a new methodology for creating prosperous new enterprises (Zehner, Trzmielak, and Gwarda-Gruszczyńska, 2014). In addition to the emergence of the first incubator in the USA, it is a common knowledge that most of them reside in the USA. According to the information revealed by the Global Network of Entrepreneurial Ecosystem Builders (INBIA), there are 1,400 incubators in the USA (INBIA, 2012).

\subsection{The Second Era between 1970 and 1990s}

Since the first inception in Batavia, the USA, incubators were not so popular until the 1970s (Jamil, Ismail, and Mahmood, 2015). The United Kingdom originated managed workspaces in their modern form in 1975, when British Steel formed a subsidiary called British Steel (Industry) - BSI - to create jobs in steel closure areas. BSI created managed workspaces, sometimes outside of old buildings and sometimes building new ones. BSI also backed many in the UK's network of enterprise agencies, which gave advice to small businesses, and became pioneer in North-West England, notably in St. Helens, which faced technological redundancies in its principal glass-making industry (OECD, 1999).

In Germany, for instance, the University of Berlin established the first incubator in 1983, which aimed at facilitating the transfer of research findings to industry, and France followed in 1985, creating the second one within the Sofia Antipolis Technology Park (Aernoudt, 2004). In the 1990s, the trend was to develop technology incubators around specific industrial and technological clusters such as biotechnology, information technology, environmental technology, or speech technology (Aernoudt, 2004).

Rustam Lalkaka (2001) summarizes the conceptual evolution of the "incubator": "The 'first generation' incubators in the 1980s were essentially offering affordable space and shared facilities to carefully selected entrepreneurial groups. In the 1990s, the need was recognized for supplementing the workspace with counselling, skills enhancement and networking services to access professional support and seed capital, for tenants within the facility and affiliates outside. This has led to the 'second generation' of incubators, although many in the developing countries are still stuck in the original mode. Starting in 1998, a new incubation 
model emerged in parallel. This is intended to mobilize ICT and provide a convergence of support, towards creating growthpotential, tech-based ventures."

\subsection{The New Era Begins with Accelerators}

In 2005, the incubation industry met another new model which is called the "accelerators." The first accelerator was Y Combinator, established in the USA by Paul Graham. They help enterprises identify and establish their initial products, find potential segments of consumers, and secure resources such as capital and employees. Exactly, accelerator programs are limited-duration programslasting roughly three months-that help cohort of ventures with the new enterprise processes. They generally supply a small amount of initial capital, including a workspace. They also provide a wide range of networking, training and mentoring opportunities with peer enterprises and mentors who may be prosperous entrepreneurs, graduates from related programs, venture capitalists, business angels, or even corporate executives. Eventually, most programs conclude with a grand event, generally a "demo day" where enterprises come together with a wide crowd of interested investors (Cohen, 2013). Today, accelerator programs have also diversified into industry-vertical focused programs, such as Surge (Houston, TX) which focuses on the acceleration of energy startups, Kaplan EdTech (New York, NY) which focuses on education-related startups, and Healthbox (Chicago and Boston) and Rock Health (San Francisco and Cambridge), which focus on acceleration of healthcare-related startups (Cohen and Hochberg, 2014).

At this level, accelerators have many similarities with incubators, but they differ in several ways. What distinguishes an incubator from other centers is that they provide clients with access to appropriate rental space and flexible leases, shared office services and equipment, technology support services, and assistance in obtaining business financing (NBIA, 2012). However, the main difference is in the limited duration of accelerator programs compared to longer-term support of incubators, angel investments, and other business support programs (Miller and Dalziel, 2018). The other difference is that incubators may acknowledge entrepreneurs that are on the idea stage; however, accelerators generally do not accept entrepreneurs that are on the idea stage.

\section{ROLE OF INCUBATORS IN THE ENTREPRENEURIAL PROCESS}

Startups stand as fundamental factors for creating jobs, and therefore, they reduce the unemployment rate in the country. Promoting entrepreneurship through incubators is necessary for economic development because incubators play a decisive role in creating successful startups. Choto argues that the task and objective of business incubators are to promote the creation and growth of the entrepreneurial venture (Choto, 2015). As an example, it is known that the number of European incubators has increased dramatically since the start of the financial crisis. Between 2007 and 2013, the number has risen by nearly 400 percent (Telefonica, 2013).

In the first four years, $50 \%$ of small businesses fail while $25 \%$ of all small businesses fail in the first year (Brain, 2016). On the other side, data from EBN and Impact Hub shows that incubated companies have a $90 \%$ survival rate within the incubation period and $87 \%$ survival rate after the incubation period (3 years) (EBN; EU|BIC, 2017).

The role of the incubator in the entrepreneurial process is not limited to being a business center with office facilities. Incubators offer training, networking, and consulting to startups. They can also help strengthen the link between capital and entrepreneurs. The Organisation for Economic Co-operation and Development (OECD) contends that entrepreneurs face several challenges in running their businesses, which hinder their full contribution towards economic growth and development, and these challenges are not limited to a lack of training and support, financial challenges, lack of skills, and a lack of entrepreneurial mindset (OECD, 2010). At this stage, business incubators are mostly regarded as providers of resources and services to entrepreneurs, including working, technical expertise, management mentoring, business administration, shared administrative services, networking, and access to new markets (Rao and Gebremichael, 2017).

According to the European Union Regional Policy (European Union, 2010), three stages of incubation are as follows:

Pre-incubation refers to all the activities required to assist the aspiring entrepreneurs in developing their business ideas, models and plans to improve the likelihood of a successful start-up. It typically includes a first evaluation of the idea, preparation and training, and guiding one to one assistance required to create a fertile environment for the client to write a full business plan. Usual examples for pre-incubators are university-affiliated ones.

Incubation relates to the assistance provided to the entrepreneur from the startup to the stage of expansion. It is normally a midterm cycle that generally lasts for the newly formed company's first three years of operation, in which it is safe to tell that the new enterprise is successful and has a reasonable chance of growing into a fully developed business. The acts usually allowed are 
access to credit, direct coaching and mentoring programs, as well as hosting and special training services. Physical incubation is only a subset of the overall incubation cycle although it is a quite valuable service.

Post-incubation is about the activities to be done after the company has attained maturity and is now able to walk on its own feet. In other words, this is the moment that the company will leave the incubator since it has been physically incubated. However, the SMEs might still need different services, such as increasing their sales or improving their efficient processes, internationalization services or implementing innovation through scouting and detection activities. The "post incubators" sometimes classify themselves as "accelerators."

All in all, making small businesses and entrepreneurial ventures contribute to the economy, there is a need for support from the incubators.

\section{TYPES OF INCUBATOR IN TURKEY}

The incubator system in Turkey is not as old as when we compare with the USA and Europe. When we look at the Turkish legal system, science parks have found their legal status with the enactment of the law on Technology Development Areas in 2001 and its implementation regulation in 2002.

The definition of an incubator, added into the Technology Development Areas Law in 2011, is as follows: "a kind of structure offers entrepreneurial companies office services, equipment support, management support, access to financial resources, critical business and technical support services provided under one roof in one hand, especially to develop young and new enterprises" (KOSGEB, 2012).

According to the implementation, the management company operates as an incubation center to train R\&D and innovative companies in the region and to develop young and new enterprises. In Turkey, there are four types of incubators which are business-based, university-based, university-private based, and finally municipality-based ones. We will explain them respectively in the following parts.

\subsection{Business-Based Incubators}

The American National Business Incubation Association (NBIA) defined business incubation as a dynamic process of business enterprise development. According to NBIA (2012), average incubation cycle times are between two and three years.

Turkey has taken part in the General Entrepreneurship Monitor Data (GEM) Project for the first time in 2006. Therefore, entrepreneurship is not an old term for Turkey (Karadeniz and Özdemir, 2009). With this respect, the useful elements to develop entrepreneurship, such as incubators, are a very new area for Turkey. For example, Cyberpark, as the world's top business incubator affiliated with the university, is the first private technology incubator of Turkey, and it was established as a business and entrepreneurship center in 2003. There are 33 incubatees inside the incubator (Bilkent Cyberpark, 2019).

Incubators such as Workup, Albaraka Garaj, and Fincube analyzed in this study fall into this category. The common feature of the three is that private banks support all of them. Isbank Turkey supports the Workup, Albaraka Turk Participation Bank supports Albaraka Garaj, and finally QNB Finansbank supports the Fincube.

\subsection{University-Based Incubators}

Universities have a central position in the economic growth of a country. Many universities establish their incubators to contribute to the ecosystem of entrepreneurship and the knowledge transfer to many industries.

Universities would not only depend on educating students, promoting research or even transferring knowledge through patents, research contracts, licenses, and spinoffs but build the mechanisms to facilitate innovation, entrepreneurial culture, developing institutes and entrepreneurial leaders, and ensure the upgraded living standard of people (Audretsch, 2012). Palumbo and Dominici (Palumbo and Dominici, 2013) define university incubators as a university-sponsored incubation system with space provision within the university and behave to promote the development of university spinoffs. Somsuk, Laosirihongthong, and McLean (Somsuk, Laosirihongthong, and McLean, 2012) classified the essential resources for university incubators to promote entrepreneurs into four main categories such as human, financial, organizational, and technological resources.

According to the research, 47 of 193 universities in Turkey have their incubators (Özdemir, 2016). ITU Cekirdek, operating under the Istanbul Technical University ARI Teknokent since 2012, was selected as the 2nd best in Europe and the third-best in the world 
by the International UBI Global index, which compares and ranks the entrepreneurship incubation centers of the leading universities in the world. ITU Cekirdek has supported 1,150 startups and 3,450 entrepreneurs so far.

Technology Development Centers (TEKMER) are incubator-like institutions established by KOSGEB in several university campuses in Turkey. TEKMER aims to help people to get trained in scientific and technological fields to become entrepreneurs, to foster the creation of new technology-based enterprises, to support the activities of existing small and medium-sized enterprises, to foster commercialization of R\&D efforts, to help efforts of development and diversification of regional economic activities and to strengthen university-industry cooperation (Akçomak, 2003). By providing support and managerial, technical, and administrative consultancy mechanisms, TEKMER aims to create new technology-based firms and to establish a suitable environment for enabling these enterprises to survive (Akçomak, 2003).

While establishing incubators, universities require less financing, infrastructure, and technical capabilities as compared to other knowledge transfer mechanisms such as science and technology parks (Jamil, 2015).

\subsection{University-Private Based Incubators}

Nowadays, the way to develop technology is to produce knowledge with the works carried out in universities and companies, and then to transform it into technology by putting the information into practice. In this regard, efficient cooperation can only be possible by developing interfaces at the public level and providing necessary incentive regulations. Therefore, a state which plays a facilitating and encouraging role in university and industry cooperation becomes vitally important. University-Industry Collaboration Centers, established within universities, are structures to ensure university and industry cooperation, and their functionality reveals with successes of the studies carried out jointly. These centers aim to contribute to students and the private sector in such areas as government incentives, human resources, education, consultancy services, scientific research, and project management.

Kworks is one of the university-industry collaboration centers in Turkey. The Acceleration Program covers a 12-week intensive mentoring process. The program includes three phases: In the first phase, startups re-evaluate the compliance of their products or services with the market. Teams also verify their business models. In the second phase, startups develop the most intelligible solutions to make their products and services more compatible with the customer and market conditions. The third phase covers an increase in sales and investment seeking processes by introducing solutions to the market. At the end of all these processes, startups graduate with a one-day Demo Day event in which investors and agents in the ecosystem come together (Kworks, 2019).

\subsection{Municipality-Based Incubators}

Municipality-based incubators are a new type of public-based incubator. They operate to benefit from the features and abilities of the public in science and technological transformation. The only difference between other types of incubators is that they are established within municipalities and supported by them. The number of such incubators might increase in the following years, considering the physical, capital, and material possibilities of municipalities. Currently, there are two municipality-based incubators in Istanbul: Zemin Istanbul (founded and supported by Istanbul Metropolitan Municipality) and Uskudar Idea Art Center.

\section{RESEARCH DESIGN, METHODOLOGY AND EMPIRICAL EVIDENCE FROM TURKISH INCUBATORS}

The purpose of this study is to analyze the impact of the incubators on entrepreneurial processes in Turkey because it seems that the number of incubations has increased rapidly, and might continue to rise more. The sample universe of this research consists of all the incubators which are operating in Turkey, and we classified them accordingly. We divided all incubators in the sample universe into four different categories, as mentioned in the Section 5. Selected incubators were analyzed by using qualitative research methodology. We used the judgmental sampling method to select an incubator out of each category, and the judicial sampling method to select three startups for each incubator. The opinion of an expert (who was the founder of a research platform called "startups.watch" that empowers interested parties (like investors) to figure out trends, transactions, and what's next via tracking startup ecosystem) was also taken into consideration in this process. On the other side, we selected the startups according to the incubators' opinion. The selected incubators and startups are listed in Table 1.

Table 1: The Incubators and Startups Analyzed in the Framework of the Study

\begin{tabular}{lccc}
\hline INCUBATORS & \multicolumn{3}{c}{ STARTUPS } \\
\hline WORKUP & Epiqur & Userguiding & Doktorderki \\
\hline
\end{tabular}




\begin{tabular}{lccc}
\hline KWORKS & Viravira.co & Vidyou & Lella App \\
\hline ITU CEKIRDEK & CatchU & FilameX & PardonApp \\
\hline USKUDAR FIKIR SANAT MERKEZI & Funsef & Notificup & Yemexpress \\
\hline ALBARAKA GARAJ & Mixoper & Yubi & Zenkronn \\
\hline FINCUBE & Price\&me & Akillisatici.com & Nkolay Ofis
\end{tabular}

The study has a significant limitation as a result of having included only the incubators operating in Istanbul. We collected data by face-to-face interviews with the officials of the incubators and founders of the startups.

Despite the differences between the types of entrepreneurial development centers, the main components of an incubation model include at least four of the five following services: (1) access to physical resources, (2) office support services, (3) access to capital, (4) process support and (5) networking services (Carayannis and Zedtwitz, 2005).

In this study, we interviewed six incubators' directors from four categories, and 18 start-ups in the incubators in Turkey (Table 1 and Table 2). The interview questions were semi-structured and designed to discover the impact of incubators on the entrepreneurship process in Turkey.

Table 2: A layout of the four incubator types

\begin{tabular}{|c|c|c|c|c|c|c|}
\hline & \multicolumn{3}{|c|}{ Business-based Incubators } & \multirow{2}{*}{$\begin{array}{c}\begin{array}{c}\text { University- } \\
\text { private based } \\
\text { Incubators }\end{array} \\
\text { KWORKS }\end{array}$} & \multirow{2}{*}{$\begin{array}{c}\begin{array}{c}\text { University-based } \\
\text { Incubators }\end{array} \\
\text { ITU CEKIRDEK }\end{array}$} & \multirow{2}{*}{$\begin{array}{c}\begin{array}{c}\text { Municipality- } \\
\text { based } \\
\text { Incubators }\end{array} \\
\text { USKUDAR FIKIR } \\
\text { SANAT MERKEZI }\end{array}$} \\
\hline & WORKUP & $\begin{array}{l}\text { ALBARAKA } \\
\text { GARAJ }\end{array}$ & FINCUBE & & & \\
\hline $\begin{array}{c}\text { The year of } \\
\text { establishment }\end{array}$ & 2017 & 2017 & 2018 & 2014 & 2012 & 2016 \\
\hline Period & 6 months & 1 year & 4 months & $11-12$ months & 1 year & Max. 18 months \\
\hline $\begin{array}{c}\text { Admission } \\
\text { Requirements }\end{array}$ & $\begin{array}{l}\text { Having a } \\
\text { technical } \\
\text { partner and } \\
\text { beyond the } \\
\text { idea stage }\end{array}$ & $\begin{array}{l}\text { A technology- } \\
\text { based startup } \\
\text { that can be } \\
\text { integrated into } \\
\text { a bank }\end{array}$ & $\begin{array}{l}\text { Specialized in } \\
\text { Fintech vertical } \\
\text { Having a team } \\
\text { and a potential } \\
\text { to cooperate } \\
\text { with QNB } \\
\text { Finansbank }\end{array}$ & $\begin{array}{l}\text { Having a } \\
\text { technical } \\
\text { partner, a team } \\
\text { and a startup } \\
\text { moving beyond } \\
\text { the idea stage }\end{array}$ & $\begin{array}{l}\text { Being a team to } \\
\text { meet the needs of } \\
\text { unique value } \\
\text { proposition for the } \\
\text { startup and to } \\
\text { have core } \\
\text { competencies to } \\
\text { put it on the } \\
\text { market }\end{array}$ & $\begin{array}{l}\text { Putting forward } \\
\text { an idea which is } \\
\text { possible to put } \\
\text { into practice, to } \\
\text { illustrate and to } \\
\text { have a future } \\
\text { potential }\end{array}$ \\
\hline \multirow[b]{2}{*}{ Facilities } & $\begin{array}{c}\text { Office, } \\
\text { Mentorship, } \\
\text { Training, } \\
\text { Network, } \\
\text { Consultancy } \\
\text { and one-on- } \\
\text { one support } \\
\end{array}$ & $\begin{array}{c}\text { Office, } \\
\text { Mentorship, } \\
\text { Training, } \\
\text { Network, } \\
\text { Consultancy } \\
\text { and one-on- } \\
\text { one support } \\
\end{array}$ & $\begin{array}{c}\text { Office, } \\
\text { Mentorship, } \\
\text { Training, } \\
\text { Network, } \\
\text { Consultancy } \\
\text { and one-on- } \\
\text { one support } \\
\end{array}$ & $\begin{array}{c}\text { Office, } \\
\text { Mentorship, } \\
\text { Training, } \\
\text { Network, } \\
\text { Consultancy and } \\
\text { one-on-one } \\
\text { support } \\
\end{array}$ & $\begin{array}{c}\text { Office, } \\
\text { Mentorship, } \\
\text { Training, Network, } \\
\text { Consultancy and } \\
\text { one-on-one } \\
\text { support }\end{array}$ & $\begin{array}{c}\text { Office, } \\
\text { Mentorship, } \\
\text { Training, } \\
\text { Network, } \\
\text { Consultancy and } \\
\text { one-on-one } \\
\text { support } \\
\end{array}$ \\
\hline & $\begin{array}{l}\text { Institutional } \\
\text { Power of } \\
\text { IsBank (the } \\
\text { first national } \\
\text { bank in } \\
\text { Turkey) }\end{array}$ & $\begin{array}{l}\text { Institutional } \\
\text { Power of } \\
\text { Albaraka Turk } \\
\text { Participation } \\
\text { Bank } \\
50.000 \mathrm{TL} \\
\text { grant for free }\end{array}$ & $\begin{array}{l}\text { Institutional } \\
\text { Power of QNB } \\
\text { Finansbank } \\
5.000 \text { USD } \\
\text { grant for free } \\
\text { for each } \\
\text { startup after } \\
\text { one-month } \\
\text { probationary } \\
\text { period }\end{array}$ & $\begin{array}{l}\text { Institutional } \\
\text { Power of Koc } \\
\text { Holding }\end{array}$ & $\begin{array}{l}\text { ITU and ITU ARI } \\
\text { Teknokent } \\
\text { Networking }\end{array}$ & $\begin{array}{l}\text { Institutional } \\
\text { Power of the } \\
\text { Municipality of } \\
\text { Uskudar }\end{array}$ \\
\hline
\end{tabular}




\begin{tabular}{|c|c|c|c|c|c|c|}
\hline $\begin{array}{l}\text { The location of } \\
\text { the incubation } \\
\text { center }\end{array}$ & $\begin{array}{l}\text { Kolektif } \\
\text { House }\end{array}$ & $\begin{array}{c}\text { Albaraka Turk } \\
\text { Participation } \\
\text { Bank }\end{array}$ & $\begin{array}{c}\text { QNB } \\
\text { Finansbank }\end{array}$ & Koc University & $\begin{array}{c}\text { Istanbul Technical } \\
\text { University }\end{array}$ & $\begin{array}{c}\text { Burhan Felek } \\
\text { Mansion }\end{array}$ \\
\hline $\begin{array}{l}\text { Expectations of } \\
\text { Incubators }\end{array}$ & $\begin{array}{l}\text { The startup } \\
\text { should } \\
\text { develop and } \\
\text { contribute to } \\
\text { the economy }\end{array}$ & $\begin{array}{l}\text { The startup } \\
\text { should sell at } \\
\text { least once in } \\
\text { that year, pivot } \\
\text { its products, } \\
\text { reach a certain } \\
\text { stage and have } \\
\text { growth } \\
\text { tendency }\end{array}$ & $\begin{array}{l}\text { Seriousness } \\
\text { and } \\
\text { determination }\end{array}$ & $\begin{array}{l}\text { The partners of } \\
\text { the startup } \\
\text { should fully } \\
\text { attend the } \\
\text { program }\end{array}$ & $\begin{array}{c}\text { Full commitment, } \\
\text { attention, good } \\
\text { utilization of ITU } \\
\text { Cekirdek }\end{array}$ & $\begin{array}{c}\text { Progress of the } \\
\text { project and its } \\
\text { level of } \\
\text { productivity }\end{array}$ \\
\hline
\end{tabular}

The similarities and differences among the facilities provided by the incubator types can be easily noticed by considering Table 2 . All the incubators offer such fundamental facilities as offices, mentorship, training, network, consultancy and one-on-one support services. The main points the incubators differ from each other are the grants, the strength of their networks, their incubator brand values, the start-up selection processes, and program durations. The shortest-term program is 4 months while the longest one lasts for 18 months.

\section{CONCLUSION}

This study analyzed the impact of incubation centers in Turkey. In this regard, we deciphered semi-structured and the face-toface interviews, which were conducted in the incubation determined by the expert opinion, and interpreted the findings in the light of the purpose of the study.

Minimum application requirements for all chosen incubation centers are "a logical idea" "beyond idea stage" and "a team." However, there may also be other admission requirements specified by the incubation centers. For example, Albaraka Garaj and Fincube, which are examples of business-based structures, prefer startups in the FinTech vertical that are possible to integrate into a bank's product and service lines.

As we can see from Table 2, the main components of an incubation model include the following services: access to physical resources, office support services, access to capital, process support, and networking services. These facilities can be accepted as primary ones since they are both the minimum services offered by each incubation center and the essential needs for a startup. In return for these primary facilities, the basic expectations of all incubation centers are the same: a startup to complete the period successfully and to become self-sufficient in the following processes. After having analyzed the primary facilities, we can say that the facilities offered by all the incubation centers compromise with the expectations of the startups operating in the centers.

In addition to the core ones, incubation centers also offer other facilities which provide various advantages for enterprises. For example, the institutional power of Isbank is the most prominent advantage of Workup. Similarly, the institutional power of Koc Holding is the main advantage of Kworks, just as the power of the network of ITU Ari Teknokent is for ITU Cekirdek, the institutional power of the Municipality of Uskudar is for Uskudar Fikir Sanat Merkezi, the institutional power of Albaraka Turk Participation Bank and the grant of 50,000 TL for free are for Albaraka Garaj, or the institutional power of QNB Finansbank and the grant of 5.000 USD for free for each startup after one-month probationary period are for the Fincube. As it is known, grants and financial resources are essential for startups in the initial phase. Startups that highly need for financial resources often choose incubation centers providing grants.

Another important criterion in determining the right incubation center for startups is its location. In general, the financial reasons and the need for convenient access make this criterion a vital one. However, it is also significant in terms of its proximity to the business center and the transportation network of the city, and its high accessibility for mentors. Startups prefer the Workup since it is in the Kolektif House, Levent, which is in the middle of the business district in Istanbul. Likewise, startups prefer Kworks for its being located in Mecidiyeköy, a central place in Istanbul, just as ITU Cekirdek is in ITU, Uskudar Fikir Sanat Merkezi is in a central and historical mansion in Uskudar, Albaraka Garaj is in the headquarters of Albaraka Turk Participation Bank, and Fincube is also situated in the headquarters of QNB Finansbank. 
Considering the establishment years of the incubation centers and the startups interviewed in the study, we can conclude that most of them were established between the years 2012 -2018. This fact indicates that there is a significant increase in the number of incubation centers and startups in Turkey. Furthermore, the opportunities and facilities offered by the state are also increasing, thus stimulating the entrepreneurship ecosystem and encouraging all stakeholders in Turkey.

As a result, the incubation centers, analyzed in the study, provide access to physical resources, office space and support services, access to capital, process and legal support, and networking services besides other value-added services.

The most important limitations of the study are that it is only limited to Istanbul (indeed, most of the startups and incubation centers are in Istanbul), that the incubation centers are selected by judicial sampling, and that the number of incubation centers is limited to 6 and the number of startups limited to 18.

In the light of the findings of this qualitative paper, a comprehensive quantitative study which will include all the incubation centers and startups operating in these centers all around Turkey could be a subject for future research.

\section{REFERENCES}

Aernoudt, R. (2004). Incubators: Tool for Entrepreneurship? Small Business Economics, 127-135.

Akçomak, S. (2003). Technology Development Centers in Turkey. Middle East Technical University.

Allen, D. N., and Nyrop, K. A. (1986). An Examination of State's Small Business Incubator Initiatives. Institute of Public Administration, Pennsylvania State University.

Allen, D. N., and Rahman, S. (1985). Small business incubators: a positive environment for entrepreneurship. Journal of Small Business Management, 23(3), 12.

Audretsch, D. (2012). From the Entrepreneurial University to the University for the Entrepreneurial Society. The Journal of Technology Transfer, 313-321.

Brain, S. (2016). Startup Business Failure Rate by Industry. Statistic Brain. Retrieved from http://www.statisticbrain.com/:http://www.statisticbrain.com/startup-failure-byindustry

Brooks, O. J. (1986). Economic development through entrepreneurship: incubators and the incubation process. Economic Development Review, 4(2), 24-29.

Cambridge Dictionary. Cambridge Advanced Learner's Dictionary and Thesaurus. Cambridge University Press. Retrieved from https://dictionary.cambridge.org/dictionary/english/incubator

Campbell, C., Kendrick, R. C., and Samuelson, D. S. (1985). Stalking the latent entrepreneur: business incubators and economic development. Economic Development Review, 3(2), 43-49.

Choto, P. (2015). The Impact of Business Incubators on Survivalist Entrepreneurs in the Cape Metropolitian Area. Cape Town: Cape Peninsula University of Technology.

Cohen, S. (2013). What Do Accelerators Do? Insights from Incubators and Angels.

Cohen, S., and Hochberg, Y. (2014). Accelerating Startups: The Seed Accelerator Phenomenon.

Culp, R. P. (1996). A test of business growth through analysis of a technology incubator program (Doctoral dissertation, Georgia Institute of Technology).

EBN; EU|BIC. (2017). Incubating Innovation Accelerating Entrepreneurship.

European Union. (2010). The Smart Guide to Innovation-Based Incubators. European Commision. Retrieved from https://ec.europa.eu/regional_policy/sources/docoffic/2007/working/innovation_incubator.pdf

Fry, F. L. (1987). The role of incubators in small business planning. American Journal of Small Business, 12(1), $51-62$.

Galante, S. P. (1987). Business incubators adopting niche strategies to stand out. Wall Street Journal, 13(1).

Hackett, S. M., and Dilts, D. M. (2004). A systematic review of business incubation research. The Journal of Technology Transfer, $29(1), 55-82$.

Hansen, M. T., Chesbrough, H. W., Nohria, N., and Sull, D. N. (2000). Networked incubators. Harvard business review, 78(5), 74-84. 
NBIA. (2012). Numbers of Entrepreneurship Centers (by Type) in US.

Jamil, F. (2015). University Incubators: A Gateway to an Entrepreneurial Society. Journal of Economics and Sustainable Development, 153-160.

Jamil, F., Ismail, K., and Mahmood, N. (2015). A Review of Commercialization Tools: University Incubators and Technology Parks. International Journal of Economics and Financial Issues, 223-228.

Karadeniz, E., and Ozdemir, O. (2009). Entrepreneurship in Turkey and developing countries: A comparison of activities, characteristics, motivation and environment for entrepreneurship. Mibes Transactions, 3(1), 30-45.

Ketchen Jr, D. J., Thomas, J. B., and Snow, C. C. (1993). Organizational configurations and performance: A comparison of theoretical approaches. Academy of management journal, 36(6), 1278-1313.

KOSGEB. (2012). Turkish Entrepreneurship Strategy and Action Plan.

KOSGEB. (2019). Retrieved from http://en.kosgeb.gov.tr/site/tr/genel/detay/347/about-kosgeb

Kuratko, D. F., and LaFollette, W. R. (1987). Small business incubators for local economic development. Economic Development Review, 5(2), 49.

Kworks. (2019). Retrieved from https://kworks.ku.edu.tr/sss/

Lalkaka, R. (2001). Best Practices in Business Incubation: Lessons (yet to be) Learnt. International Conference on Business Centers: Actors for Economic \& Social Development.

Lichtenstein, G. A. (1992). The significance of relationships in entrepreneurship: A case study of the ecology of enterprise in two business incubators.

Lumpkin, J. R., and Ireland, R. D. (1988). Screening practices of new business incubators: the evaluation of critical success factors. American Journal of Small Business, 12(4), 59-81.

Lynn, L. H., Reddy, N. M., and Aram, J. D. (1996). Linking technology and institutions: the innovation community framework. Research policy, 25(1), 91-106.

Miller, C., and Dalziel, M. (2018). How to Benchmark Accelerators and Other Business Support Programs. Business Finland.

Nohria, N., and Eccles, R. G. (1992). Networks and organizations: Structure, form, and action.

Nye, J. V. (1991). Lucky fools and cautious businessmen: on entrepreneurship and the measurement of entrepreneurial failure. The Vital One: Essays in Honor of Jonathan RT Hughes. Research in Economic History, 6, 131-52.

OECD. (1999). Technology Incubators:Nurturing Small Firms. Paris.

OECD. (2010). Lessons from the Global Crisis and the Way Forward to Job Creation and Growth. Paris.

Özdemir, B. (2016). Girişimciliğin Desteği Olarak Üniversite Kuluçka Merkezleri, Türkiye Perspektifi. 2nd International Congress on Economics and Business (s. 115-124). Manisa Celal Bayar Üniversitesi.

Palumbo, F., and Dominici, G. (2013). University Incubator as Catalyst of Resources for Academic Spin-Offs: The Case of Arca Consortium. Recent Advances in Business Management and Marketing, 209-218.

Plosila, W. H., and Allen, D. N. (1985). Small business incubators and public policy: implications for state and local development strategies. Policy Studies Journal, 13(4), 729-734.

Rao, S., and Gebremichael, H. (2017). How Does Business Incubation Affect Growth of Firms? Evidence from Ethiopia. Global Journal for Research Analysis, 547-550.

Rice, M. P. (2002). Co-production of business assistance in business incubators: an exploratory study. Journal of business venturing, 17(2), 163187.

Somsuk, N., Laosirihongthong, T., and McLean, M. (2012). Strategic Management of University Business Incubators (UBIs): Resource-Based View (RBV) Theory. IEEE International Conference on Management of Innovation \& Technology (ICMIT), 611-618.

Telefonica (2013). The Accelerator and Incubator Ecosystem in Europe.

Temali, M., and Campbell, C. (1984). Business incubator profiles: a national survey. Hubert H. Humphrey Institute.

Torun, M., Peconick, L., Sobreiro, V., and Kimura, H. (2018). Assessing Business Incubation: A Review on Benchmarking. International Journal of Innovation Studies.

Willianson, O. E. (1975). Markets and hierarchies: analysis and antitrust implications. New York. 
Zehner, W., Trzmielak, D., and Gwarda-Gruszczyńska, E. (2014). Business Incubation in the USA. Researchgate, s. 145-162.

\section{Appendix 1}

The questions for the directors of the incubators are as follows

1. What criteria do you look for when you accept a new entrepreneur?

2. What are your expectations from entrepreneurs?

3. What are the facilities you offer to entrepreneurs?

4. What are the challenges you have with entrepreneurs?

5. Are you satisfied with the situation of incubators in Turkey? Can you evaluate this positioning?

6. Can you share your growth targets with your future targets?

\section{The questions for entrepreneurs in the incubators are as follows}

1. Why did you choose this incubator? What criteria did you consider?

2. How much did your incubation center increase your potential? Did your startup accelerate after entering the incubation center?

3. What problems do you have in the incubator?

4. What are your expectations from an incubator center?

5. Are you satisfied with the situation of incubators in Turkey? Can you evaluate this positioning? 